\title{
Mortality and causes of death in Dutch haemophiliacs,
} 1973-86

\author{
F. R. RosendaAl, ${ }^{1}$ I. VAREKamp, ${ }^{2}$ C. SMIT, ${ }^{1,3}$ A. H. J. T. BröcKer-VRIends, ${ }^{4}$ H. VAN DijCK, ${ }^{3}$ \\ J. P. Vandenbroucke, ${ }^{5}$ J. Hermans, ${ }^{6}$ T. P. B. M. SuUrmeijer ${ }^{2}$ and E. Brrët ${ }^{1}{ }^{1}$ Department of Haematology, \\ University Hospital Leiden, ${ }^{2}$ Department of Medical Sociology. State University Groningen, \\ ${ }^{3}$ Dutch Haemophilia Society (NVHP), ${ }^{4}$ Clinical Genetics Centre Leiden, \\ ${ }^{5}$ Department of Clinical Epidemiology, University Hospital, Leiden, and \\ ${ }^{6}$ Department of Medical Statistics, State University Leiden, The Netherlands
}

Received 29 February 1988; accepted for publication 7 July 1988

Summary. Mortality figures were calculated for a group of 717 Dutch haemophiliacs over the period 1973-86. Followup was on average 10.9 years; no patients were lost to followup. The data were compared to the general male population by actuarial methods and patient-year analysis. Forty-three patients died, while 20 deaths were expected in a hypothetical group of non-haemophiliacs of the same age distribution. Hence, overall mortality was $2 \cdot 1$ times higher than in the general population. This leads to a calculated life expectancy of 66 years, as compared to 74 years in the general male population. Mortality did not differ much by severity of haemophilia. A possibly beneficial effect of prophylaxis on longevity was observed. Haemorrhage occurred in half of all deaths and among these traumatic bleeding was the most prevalent. The number of deaths due to ischaemic heart disease was significantly lower ( $80 \%$ reduction) than expected and therefore the authors conclude that haemophilia offers protection against ischaemic heart disease. Cancer mortality was significantly higher $(2.5$ times $)$ than expected.
Life expectancy in haemophilia was very low until the introduction of coagulation factor preparations made effective replacement therapy possible. Patients with severe haemophilia usually did not live beyond early adulthood, while even the life expectancy in mild haemophilia was reduced to about two-thirds of the normal life span (Sjölin, 1960; Ramgren, 1962; Ikkala et al, 1982; Larsson, 1985). Recently, Larsson (1985) reported a much improved median life expectancy of 57 years in severe haemophilia over the period 1961-80. Although this figure was still markedly below that of the general population, he also observed that the death rates for the younger patients in the last 10 years of his study were approaching those of the general Swedish population. Johnson et al (1985) found the age-adjusted mortality among United States haemophiliacs during 197882 to be 2.3 times as high as that of the general male population. Some deaths may have been missed, however, since this result was based on reported deaths and visits to haemophilia centres, rather than on a cohort study.

Before 1960, virtually all deaths in haemophilia were

Correspondence: Dr E. Briët, Department of Haematology, Building 1, C2-R, University Hospital Leiden, P.O. Box 9600, NL-2300 RC Leiden, The Netherlands. caused by haemorrhage (Nour-Eldin, 1961; Ramgren, 1962; Ikkala et al, 1982; Wolff et al, 1986). The increased life expectancy and the concomitant increased average age of haemophiliacs now make it possible to study the occurrence of other causes of death in haemophilia and to compare these with the expected frequencies based on mortality figures from the general population. We set out to calculate mortality figures in haemophilia, based on haemophilia surveys that we started in 1973 .

\section{METHODS}

The data were derived from haemophilia surveys carried out in 1973, 1978 and 1986. These surveys consisted of mail questionnaires sent to the Dutch haemophiliacs. The patients were enrolled through the major Dutch haemophilia treatment centres and the Dutch Haemophilia Society.

Severity of haemophilia was defined by the percentage of factor VIII or factor IX clotting activity: severe haemophilia less than $1 \%$, moderate haemophilia $1-5 \%$, and mild haemophilia more than $5 \%$ clotting activity. If necessary, the information from the patients' forms was supplemented with data from the haemophilia treatment centres.

Follow-up was performed for the respondents of the first two surveys and extended from either 1 January 1973 or 1 
Table I Distribution of patients by type and severity of haemophilıa

\begin{tabular}{|c|c|c|c|c|c|c|}
\hline \multirow[b]{2}{*}{ Severity } & \multicolumn{2}{|c|}{ Type A } & \multicolumn{2}{|c|}{ Type B } & \multirow{2}{*}{$\begin{array}{l}\text { Inhibitor } \\
\text { patients }(n)\end{array}$} & \multirow{2}{*}{$\begin{array}{l}\text { Mean age at } \\
\text { entrance (yr) }\end{array}$} \\
\hline & $n$ & $\%$ & $n$ & $\%$ & & \\
\hline Severe & 275 & 45 & 46 & 46 & 24 & 202 \\
\hline Moderate & 139 & 23 & 30 & 30 & 4 & 212 \\
\hline Mild & 202 & 33 & 25 & 25 & 2 & 282 \\
\hline All & 616 & & 101 & & 30 & 230 \\
\hline
\end{tabular}

June 1978 up to 1 January 1986, which were the closing dates of the three surveys Information was obtamed about all 717 patients who responded to the previous surveys, either from their response to the latest survey, or by inquiries of the municipal registries In this way none of the individuals was lost to follow-up

We compared mortality in our patient group with the general population in two ways Both allowed the expression of mortality as a ratio of observed over expected mortality First, the actuarial survival was calculated by life table methods, and compared with the survival of a hypothetical cohort of identical age distribution from the general male population So, we incorporated the national mortality figures for all consecutive years of the follow-up period (Netherlands Central Bureau of Statistics, 1973-86, 1984) Secondly, we compared cause-specific mortahty by the patient-year method This calculation was performed by multiplymg the number of patient-years of follow-up for each age category of the cohort with the corresponding causespecific mortality rates in the general male population, and summing over the age classes The observed/expected ratio arrived at in this way is the standardized mortality ratio (SMR) In the calculation of cause specific mortality the population figures of 1979 were used For statistical analysis we used the Poisson distribution to calculate confidence limits and exact sıgnificance levels and chı-square tests

\section{RESULTS}

Mortality figures were calculated for a cohort of 717 patıents, consisting of the respondents of the 1973 and 1978 surveys A response rate of $84 \%$ to the first and $70 \%$ to the second survey resulted in 481 patients entering the study in 1973, while an additional 236 entered in 1978 An extensive and by all practical means exhaustive search led to a mailıng to 1162 haemophllacs in our latest survey in 1986 This number, considering a population of 145 millon Dutch, gives a prevalence of eight per 100000 , so it can be inferred that the cohort of 717 patients formed about $65 \%$ of all Dutch haemophiliacs, when we take the growth of the general population into account Nine hundred and thirty-five patients responded in our 1986 survey (80\%) Mean followup was 109 years None of the 717 patients was lost to follow-up The mean age at entrance in the study was 23 years Table I shows the general characteristics of the cohort of 717 patients

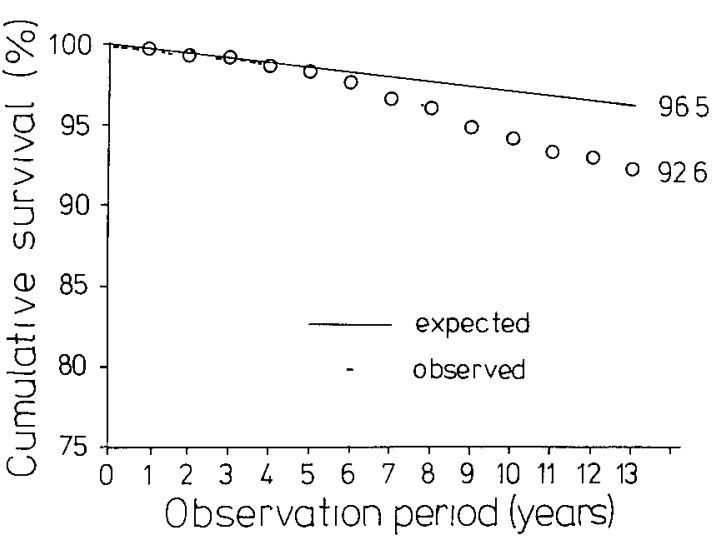

Fig 1 Cumulative survival in haemophilia 197386 The open line shows the observed survival over the interval 1973-86 The closed line shows the expected survival The distance from $100 \%$ is the mortality $74 \%$ observed and $35 \%$ expected

Forty-three patients died during the study interval, while 204 deaths were expected when we applied age-specific population mortality rates Therefore, relative mortality, the ratio of observed over expected mortality, was 21 , 1 e mortality was twice as high in the haemophiliacs as in the general male population (FIg 1) Relative mortality was 29 in severe, and only $16 \mathrm{~m}$ mild haemophilua When we excluded the small group of inhibitor patıents, however, relative mortality did not differ much by severity of haemophilıa The mean age of death was 49 years The median life expectancy was calculated also by Iffe table method, by applying the population mortality figures multiplied by the relative mortality at each age interval For this calculation to be valid an equal distribution of relative mortality over age has to be assumed The median life expectancy is the age at which half of a hypothetical cohort of newborns had died It was 74 years for the Dutch male population, and estımated at 66 years for a relative mortality of 21 (Table II)

Among the patients with severe haemophilia $24(7 \%)$ had an inhibitor Six of these patients died, but only 14 of the 297 patients without an unhibitor died $\left(\chi^{2}=124, P<00004\right)$ Inhibitor patients had a 53 times higher risk of dyıng than the patients without an mhibitor (95\% confidence interval 1 9-11 5) This was not due to a difference in age on the contrary, the inhibitor patients were on average slightly younger (half a year) at therr entrance to the study than the other patients with severe haemophilıa

One hundred and twenty-nme (43\%) of the 297 patients with severe haemophilia, inhibitor patients excluded, received prophylactic substitution therapy during the whole or, more frequently, part of the study interval Only three deaths occurred in the prophylaxis group, while 11 patients died among the 168 haemophliacs who did not receive prophylaxis Part of this difference was caused by a different age-distribution patients receiving prophylaxis were on average 5 years younger at their entrance in this study After age adjustment, however, mortality was still lower in the patients who received prophylactic treatment the relative mortality was 19 , as compared to 25 among the patients who were not treated prophylactically This difference was 
Table II. Relatıve mortality in haemophilia by severity of haemophilia*

\begin{tabular}{|c|c|c|c|c|c|c|}
\hline Group & $\begin{array}{l}\text { No of } \\
\text { patients }\end{array}$ & $\begin{array}{l}\text { Patient- } \\
\text { years } \\
\text { (yr) }\end{array}$ & $\begin{array}{l}\text { No } \\
\text { of deaths }\end{array}$ & $\begin{array}{l}\text { Relative } \\
\text { mortality, } \\
\mathrm{O} / \mathrm{E}\end{array}$ & $\begin{array}{l}95 \% \\
\text { confidence } \\
\text { interval }\end{array}$ & $\begin{array}{l}\text { Median } \\
\text { life- } \\
\text { expectancy } \\
\text { (yr) }\end{array}$ \\
\hline \multicolumn{7}{|c|}{ Including patients with an inhibitor } \\
\hline All & 717 & 7788 & 43 & 21 & $151-280$ & 66 \\
\hline Severe & 321 & 3653 & 20 & 29 & $177-448$ & 63 \\
\hline Moderate & 169 & 1863 & 10 & 23 & $109-418$ & 65 \\
\hline Mild & 227 & 2263 & 13 & 16 & $086-277$ & 69 \\
\hline \multicolumn{7}{|c|}{ Excluding patients with an mhibitor } \\
\hline All & 687 & 7467 & 36 & 18 & $128-251$ & 68 \\
\hline Severe & 297 & 3404 & 14 & 23 & $127-390$ & 65 \\
\hline Moderate & 165 & 1817 & 10 & 23 & $111-426$ & 65 \\
\hline Mild & 225 & 2247 & 12 & 15 & $076-258$ & 70 \\
\hline
\end{tabular}

* Relative mortality is the ratıo of observed over expected mortality, as found by life table method The $95 \%$ confidence interval applies to this ratio Median life expectancy was also calculated by life table method, with application of the appropnate relative mortality over each 1-year interval Normal median life expectancy (males, 1976-80) is 74 years

Table IV. Observed and expected frequency of death causes*

Table III. Causes of death ${ }^{7}$

\begin{tabular}{lcc}
\hline Cause & \multicolumn{2}{c}{ No of deaths } \\
\hline Bleeding & 3 & $20^{\mathrm{b}}$ \\
$\quad$ intracranial & $6^{\mathrm{c}}$ & \\
traumatic & $2^{\mathrm{d}}$ & \\
renal fallure & $1^{\mathrm{d}}$ & \\
suicide & 1 & \\
$\quad$ digestive tract & 1 & \\
postoperatively & $2^{\mathrm{d}}$ & \\
$\quad$ carcinoma & 4 & \\
$\quad$ other & & $3^{\mathrm{c}}$ \\
Stroke syndrome & & 15 \\
Neoplasm & & 2 \\
Sulcide & & 1 \\
Myocardial infarction & & 3 \\
Renal fallure & & 1 \\
Allergic reaction & & $3^{\mathrm{f}}$ \\
Unknown & & 43 \\
Total & & \\
\hline
\end{tabular}

a In all but four cases causes of death were obtained from physicians in the remaining cases from family members

${ }^{6}$ Five cases also counted under causes beneath, indicated by note (d)

' Accompanied with head injury in three to five cases

d Also counted under specified heading below

c Haemorrhage or thrombosis unknown (aged $53,78,82$ years)

$f$ Aged 23, 43 and 48 years

\begin{tabular}{|c|c|c|c|}
\hline Cause & $\begin{array}{l}\text { Expected } \\
\text { number }\end{array}$ & $\begin{array}{l}\text { Observed/ } \\
\text { expected } \\
\text { ratıo }\end{array}$ & $\begin{array}{l}95 \% \text { confidence } \\
\text { interval }\end{array}$ \\
\hline Neoplasm & 59 & 25 & $14-42$ \\
\hline Lung cancer & 07 & 86 & $31-187$ \\
\hline Accidents & 23 & 26 & $10-57$ \\
\hline Suicide & 08 & 25 & $\begin{array}{llllllll}0 & 3-9 & 0\end{array}$ \\
\hline Stroke syndrome & 12 & 50 & 18109 \\
\hline Renal failure & 01 & 300 & $60-880$ \\
\hline Ischaemic heart disease & 50 & 02 & $00-11$ \\
\hline
\end{tabular}

* The expected number of deaths was calculated by patient-year analysıs, the observed/expected ratio is the standardızed mortality ratıo (SMR) The 95\% confidence interval applies to this ratıo

not statıstically significant, but the power to detect such a difference was weak, due to the small number of deaths

Causes of death could be obtained in 40 out of 43 deceased patients (Table III) At least 20 deaths were caused by haemorrhage, although in several patients an underlynng lethal disorder existed Traumatic bleeding was the most prevalent. One death was caused by an allergic reaction to cryoprecipitate with glotis oedema, in three deaths the cause was renal disease, a frequent complication in haemophilia (Prentice et al, 1971; Lazerson, 1976). No other therapyassociated deaths occurred: no cases of AIDS among haemophiliacs were known in the Netherlands at the end of the follow-up period and none of the reported death causes could be attributed to AIDS Specifically, there were no tumours of lymphatic tissue or opportunistic infections Surprisingly, no 
deaths caused by liver disease were reported. All deaths in inhibitor patients were caused by bleeding. Five of the 11 deaths in patients with severe haemophilia not treated prophylactically were associated with haemorrhage, but none of the three deaths in the patients receiving prophylaxis.

Patient-year analysis provided the age adjusted expected number of deaths for each cause (Table IV). This showed a higher-than-expected mortality of several causes that are not (directly) associated with the bleeding tendency. For neoplasms the observed number of deaths was $2 \cdot 5$ times the expected number. More than half of this excess cancer mortality was caused by lung tumours. In sharp contrast to this, the number of deaths from ischaemic heart disease was lower than the calculated expected number: while five were expected only one was observed, a significant reduction $(P=0 \cdot 03$, one-sided test $)$. This low mortality due to ischaemic heart disease occurred in the face of a high prevalence of hypertension, at least as judged by the use of antihypertensive medication. In our latest survey we found $26 \%$ of the severely affected patients aged $40-65$ to use antihypertensive drugs, compared to $8 \%$ in moderate and mild haemophilia.

\section{DISCUSSION}

Our results indicate a mortality risk in haemophilia that is twice the risk that applies to the general male population. This implies an enormous advance compared to only a few decades ago, but still leads to a calculated loss of 8 years on median life expectancy. Most improvement has been made in severe haemophilia, and hence the death rates in severe, moderate and mild haemophilia were not very different. Inhibitor patients had a far less favourable prognosis. Analysis of the causes of death revealed a very low occurrence of deaths due to ischaemic heart disease, while an excess of neoplastic deaths, especially from lung cancer, was observed.

The patient group of this study was formed by the respondents of our mail surveys of 1973 and 1978. Because of the high overall response rate of $79 \%$ and the long period of follow-up we do not think that non-response introduced an important bias. It is likely, however, that selection occurred before the questionnaires were sent in the acquisition of addresses from the major haemophilia care centres and the Dutch Haemophilia Society. Patients with mild haemophilia probably are underrepresented, since their disease may remain undetected for many years if not for life and, moreover, because many of these patients are not registered in a major haemophilia centre.

We are confident that the acquisition of addresses of the severely affected patients was fairly complete. The 321 patients with severe haemophilia were included by sending questionnaires to over 400 patients. If these were all patients with severe haemophilia living in 1979 , the prevalence of severe haemophilia would be $3 \cdot 1 / 100000$, which is similar to (Rizza \& Spooner, 1983) or higher than (Larsson et al, 1982) figures from reports from countries with excellent registration systems. For our 1986 survey we carried out a far more extensive search, also including many small hospitals. This study, in our judgement, includes practically all known Dutch haemophiliacs. Our efforts, however, did not lead to an increased number of addresses of patients with severe haemophilia, whereas $50 \%$ more patients with mild haemophilia were included. This implies that selection was limited to mild haemophilia.

Prophylactic substitution therapy possibly reduces mortality in comparison to 'on-demand' treatment. Intensive therapy also carries the risk of transfusion-transmitted diseases. In our study deaths from AIDS or liver disease were absent. The prevalence of antibodies to the human immunodeficiency virus (HIV) among Dutch haemophiliacs is lower than in many other countries: $21 \%$ for severe haemophilia (Rosendaal et al, 1988). This is most likely due to the predominant use of plasma products from local nonpaid donors and a large use of cryoprecipitate in The Netherlands. As Wolfs et al (1988) pointed out, about half of the seroconversions occurred after 1983, which serves as a further explanation for the absence of AIDS cases up to 1 January 1986.

Aronson (1988), reporting on almost 1000 deaths of U.S.A. haemophiliacs from 1968 to 1979 , found $9 \%$ of deaths to be caused by liver disease. Among 107 deaths of haemophilia patients in Great Britain between 1976 and 1980, 2\% died of liver disease, while about half of the patients were treated with commercially produced plasma products (Rizza \& Spooner, 1983). These data suggest that the origin of the clotting factor preparations plays a role in the prevalence of liver disease, as has been reported by Spero et al (1979). Aledort et al (1985), however, found no association between the occurrence of severe liver disease and the product used.

We observed a large excess of cancer deaths, which was in part caused by neoplasms of the lung. Since the chance of surviving a carcinoma of the lung is generally low, this can only be fully explained by a raised incidence. A simple hypothesis is that haemophiliacs smoke more often than others, which might be related to their physical disability. The administration of blood transfusion during surgery has been reported to lead to less rejections of renal transplants (Opelz et al, 1973), and higher recurrence rates of malignancies (Burrows \& Tarttes, 1982), possibly caused by immunosuppression. Immune alterations have also been demonstrated in poly-transfused haemophiliacs (Brettler et al, 1986; Madhok et al, 1986). Although the role of the clotting system in metastasis is a matter of controversy (Bastida, 1985), it may well be possible that the absence of fibrin formation around microscopic tumours enhances early metastasis in haemophilia patients which, combined with immune abnormalities, raises the cancer incidence.

The relative mortality due to ischaemic heart disease was significantly lower in haemophiliacs than in the general male population. This reduction is remarkable when viewed in the light of the raised mortality of many other causes. The high prevalence of hypertension among haemophiliacs makes this finding even more impressive. Autopsy series have shown that haemophilia does not prevent the development of atherosclerosis (Dalldorf et al, 1981; Small et al, 1983). Consequently, we think that delayed fibrin formation may 
protect patients with haemophilia against coronary thrombosis and myocardial infarction (DeWood et al, 1980; Report of the Sixty-plus Reinfarction Study Research Group, 1980). This protection is only partial, since myocardial infarction in haemophiliacs has been reported occasionally (Boivin, 1954; Borchgrevink, 1959). Three earlier reports on deaths in haemophilia, together reporting on more than 200 deaths, also seem to show a deficit of deaths by myocardial infarction (Johnson et al, 1985; Rizza \& Spooner, 1983; Schiller et al, 1985), although we were not able to calculate the combined observed-expected ratio from the published data. One report, covering 118 deaths over the period 1957-80 in Sweden. does not show a deficit (Larsson \& Wiechel, 1983). Aronson (1988) found an inversed ratio of the number of cancer deaths over the number of deaths from ischaemic heart disease, suggestive of a decreased mortality from heart disease or an increased cancer mortality, or both. Since the life expectancy of haemophiliacs is gradually becoming normal, more patients will live to experience diseases of the elderly like ischaemic heart disease and a deficit will be easier to observe.

When studying mortality over a 13-year interval, recent changes are not reflected fully in the data. In the last few years, inhibitor patients have received treatment with low dose substitution therapy which leads to the disappearance of many inhibitors (Van Leeuwen et al, 1986). Therefore, it is likely that the prognosis for these patients is far better now than during the years of our study. In the immediate future AIDS, as well as liver disease, will have an effect on mortality, the impact of which may differ from country to country. However devastating, these effects will be temporary. For the future we expect the disappearance of possible carry-over effects from the past, when more and more patients will have received adequate therapy from childhood.

\section{ACKNOWLEDGMENTS}

We gratefully acknowledge the cooperation of the patients and the haemophilia treatment centres that made this study possible. Dr W. A. van Stiphout kindly gave her advice. Mrs R. M. Claassen-Tegelaar diligently prepared the manuscript. This study was made possible by financial support from Het Praeventiefonds (28-1099) and De Stichting Haemophilia.

\section{REFERENCES}

Aledort, L.M., Levine, P.H., Hilgartner, M., Blatt, P., Spero, J.A., Goldberg, J.D., Bianchi, L., Desmet, V., Scheuer, P., Popper, H. \& Berk, P.D. (1985) A study of liver biopsies and liver disease among hemophiliacs. Blood, 66, 367-372.

Aronson, D.L. (1988) Cause of death in hemophilia A patients in the United States from 1968 to 1979. American Journal of Hematology. 27, $7-12$.

Bastida, E. (1985) The metastatic cascade: potential approaches for the inhibition of metastasis. Seminars in Thrombosis and Hemostasis, $14,66-72$.
Boivin, J.M. (1954) Infarctus du myocarde chez un hémophile. Mal du Coeur, 47, 351-354.

Borchgrevink, C.F. (1959) Myocardial infarction in a haemophiliac. Lancet, i, 1129-1230.

Brettler, D.B., Forsberg, A.D., Brewster, F., Sullivan, J.L. \& Levine, P.H. (1986) Delayed cutaneous hypersensitivity reactions in hemophiliac subjects treated with factor concentrate. American Journal of Medicine, 81, 607-611.

Burrows, L. \& Tartter, P. (1982) Effect of blood transfusion on colonic malignancy recurrence rate. Lancet, ii, 662.

Dalldorf, F.G., Taylor, R.E. \& Blatt, P.M. (1981) Arteriosclerosis in severe hemophilia: a postmortem study. Archives of Pathology and Laboratory Medicine, 105, 652-654.

DeWood, M.A., Spores, J., Notske, R., Mouser, L.T., Burroughs, R., Golden, M.S. \& Lang, H.T. (1980) Prevalence of total coronary occlusion during the early hours of transmural myocardial infarction. New England Journal of Medicine, 303, 897-902.

Ikkala, E., Helske, T., Myllyla, G., Nevanlinna, H.R., Pitkanen, P. \& Rasi, V. (1982) Changes in the life expectancy of patients with severe haemophilia in Finland in 1930-79. British Journal of Haematology, 52, 7-12.

Johnson, R.E., Lawrence, D.N., Evatt, B.L., Bregman, D.J., Zyla, L.D., Curran, J.W., Aledort, L.M., Eyster, M.E., Brownstein, A.P. \& Carman, C.J. (1985) Acquired immunodeficiency syndrome among patients attending hemophilia treatment centers and mortality experience of hemophiliacs in the United States. American Journal of Epidemiology, 121, 797-810.

Larsson, S.A., Nilsson, 1.M. \& Blomback, M. (1982) Current status of Swedish hemophiliacs. Acta Medica Scandinavica, 212, 195-200.

Larsson, S.A. \& Wiechel, B. (1983) Deaths in Swedish hemophiliacs, 1957-1980. Acta Medica Scandinavica, 214, 199-206.

Larsson, S.A. (1985) Life expectancy of Swedish haemophiliacs, 1831-1980. British Journal of Haematology. 59, 593-602.

Lazerson, J. (1976) Renal disease in hemophilia. Hemophilia in Children (ed. by M. W. Hilgartner), pp. 71-78. Acton Mass Publishing Sciences Group, Acton.

Madhok, R., Gracie, A., Lowe, G.D.O., Burnett, A., Froebel, K., Follett, E. \& Forbes, C.D. (1986) Impaired cell mediated immunity in haemophilia in the absence of infection with human immunodeficiency virus. British Medical Journal, 293, 978-980.

Netherlands Central Bureau of Statistics (CBS) (1973-86) Overledenen naar doodsoorzaak, leeftijd en geslacht (Mortality by cause. age and sex): series A1 and B1. Staatsuitgeverij. The Hague.

Netherlands Central Bureau of Statistics (CBS) (1984) Life table by marital status, 1976-1980. Table 3B, p. 67. Staatsuitgeverij, The Hague.

Nour-Eldin, F. (1961) Longevity of haemophiliacs. British Medical Journal, i, 824 .

Opelz, G., Sengar, D.G.S., Mickey, M.R. \& Terasaki, P.I. (1973) Effects of blood transfusion on subsequent kidney transplants. Transplantation Proceedings, 5, 253-259.

Prentice, C.R.M., Lindsay, R.M., Barr, R.D., Forbes, C.D., Kennedy, A.C., McNicol, G.P. \& Douglas, A.S. (1971) Renal complications in haemophilia and Christmas disease. Quarterly Journal of Medicine, 157, 47-61.

Ramgren, O. (1962) Haemophilia in Sweden: part 2. Acta Medica Scandinavica (Suppl.). 937s, 37-60.

Report of the Sixty-plus Reinfarction Study Research Group (1980) A double blind trial to assess long-term oral anticoagulant therapy in elderly patients after myocardial infarction. Lancet, ii, 989-994.

Rizza, C.R. \& Spooner, R.J.D. (1983) Treatment of haemophilia and related disorders in Britain and Northern Ireland during 19761980: report on behalf of the directors of haemophilia centres in the United Kingdom. British Medical Journal, 286, 929-933.

Rosendaal, F.R., Smit, C., Varekamp, I., Bröcker-Vriends, A., Suur- 
meljer, T P B M \& Briet, E (1988) AIDS and haemophlia a study among Dutch haemophliacs on the psychosocial impact of the AIDS threat, the prevalence of HIV antibodies and the adoption of measures to prevent HIV transmission Haemostasis 18, 73-82

Schiller, W G. Hartmann G \& Remde, W (1985) Todesursachen von Hamophilsepatienten in der DDR Folla Haematologica (Leipzig) $112,845-852$

Sjolin, K E (1960) Haemophilc Diseases in Denmark Blackwell Scientific Publications, Oxford

Small, M Jack, A S, Lowe, GD O, Mutch, A 5 Forbes CD \& Prentice, C R M (1983) Coronary artery disease in haemophilia British Heart Journal 49, 604-607

Spero. J A Lewis, JH Fisher, SE, Hasiba, U \& Van Thiel DH (1979) The high risk of chronic liver disease in multıtransfused
Juvenile hemophiliac patients Journal of Pedatrics 94, 875-878 Van Leeuwen, E F, Van Dıjken, P J , Mauser-Bunschoten, E P , Kok, A J Sjamsoedın-Visser E J M \& Sixma, J J (1986) Disappearance of factor VIII $C$ antibodies in patients with haemophilia $A$ upon frequent administration of factor VIII in intermediate or low dose British Journal of Haematology 24, 291-294

Wolff, L J , Dwyer, C A \& Lovrien E W (1986) Deaths in Oregon hemophiliacs (Abstract) Clmical Research, 34, 125A

Wolfs TFW, Breederveld, C Krone W JA Van den Hoek L, Bakker M Smit L Goudsmit, ] \& the Dutch hdemophilia group (1988) HIV-antibody seroconversions in Dutch haemophiliacs using heat-treated and non heat-treated coagulation factor con centrates Thrombosis and Haemostasis, 59,396 399 